\title{
Lifetime Achievement in Counseling Series An Interview With Michael Ryan
}

\author{
Joshua D. Smith, Neal D. Gray
}

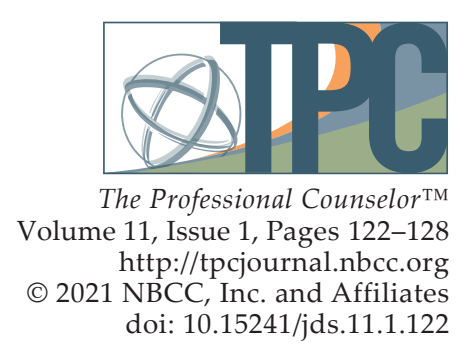

Each year TPC presents an interview with a seminal figure in counseling as part of its Lifetime Achievement in Counseling series. This year I am honored to introduce Michael Ryan. He identifies as a professional school counselor and advocate and shares his experiences and perspective on the professionalization of school counseling. I am grateful to Dr. Joshua Smith and Dr. Neal Gray, who continue to bring the contributions and vision of leaders in the profession to TPC readers. Their interview with Ryan provides a view to his path to school counseling, his work to meet the needs of underrepresented student populations, and how he empowers students and staff as agents of change and in so doing promotes a clear understanding of the roles and responsibilities of professional school counselors within his community. I imagine his approach may both resonate with and energize TPC readers. - Amie A. Manis, Editor

Michael Ryan, MEd, NCC, is a certified school counselor and currently is the Coordinator of Student Supports for Monongalia County Schools in Morgantown, West Virginia. He holds a BA in psychology from West Virginia University, an MEd with a school counseling concentration from California University of Pennsylvania, and a higher education certification from Salem International University with his Principal, District Administrator, and Superintendent certification.

Prior to his current position, Ryan was an elementary school counselor for 6 years in Monongalia County. During that time, he was named the 2018 West Virginia School Counselor of the Year. He also did work in career counseling at a college as well as community mental health counseling prior to becoming a school counselor.

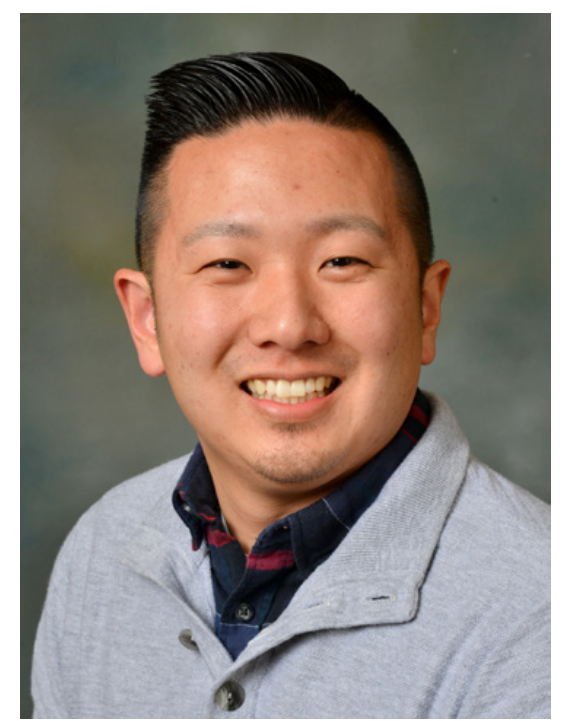

In Ryan's current position, he is responsible for providing student supports for almost 12,000 students in the county across Pre-K through 12th grade. He has been instrumental in coordinating socialemotional learning practices for the county and helping to implement a multi-tiered system of supports (MTSS) model that looks at the whole student and is consistent from school to school. He is the head of the Diversity, Equity, and Inclusion Department of the county, which he had the privilege of building from the ground up. He is also responsible for providing professional development to the county staff in areas such as social-emotional learning, trauma-informed practices, and diversity and inclusion.

Ryan is an active member of the surrounding community and multiple organizations, through which he builds relationships to help find support for the students of the county. He is a part of the West Virginia School Counseling Association governing board and a member of the American School Counselor Association.

In this interview, Ryan shares his insights on growth and change within the school counseling profession, his path to becoming a school counselor, his passion for advocacy, and the importance of unified practices to benefit each person in the community. 


\section{What led you to pursue a degree in counseling compared to other helping professions?}

I didn't have a typical path to my career. I was one of those students coming out of high school who didn't really have an idea of what I wanted to do. I went to a small, rural high school and didn't have a lot of exposure to things. Sports were pretty much my life, and when I was deciding on majors, I went through the sports programs and settled on sports management because it made the most sense to me at that time. I ended up going to West Virginia University (WVU) because it was close to home and I was around WVU all my life. My family had season tickets to the football games, and those were some of the earliest memories that I have. It was my second home.

After my first year at WVU, I ended up taking a year off. I was very lost on what I wanted to do for the rest of my life, and nothing made sense to me. Every time someone brought something up as a suggestion, I struggled because I couldn't picture myself doing any of those things. I knew I didn't want to do something that wasn't going to make me happy.

During this time Texas hold 'em poker was big. I remember being intrigued by it and wanting to learn how to play. I started out playing for fun online with fake money, but eventually I started to play with real money. I had no idea what I wanted in life, but gambling gave me an escape from the real world, whether I won or lost (I lost more than I won). This year off was not a productive year for me, and I ended up becoming addicted to gambling and losing all the money that I had. It was at the point where I needed to borrow money from my friends that I realized I had a problem. I knew I couldn't keep going down the road I was on and I needed a change of scenery.

Then, I watched the movie Ladder 49 and all of a sudden, I had this urge to be a firefighter. So, I applied to fire school in Fairfax, Virginia, but it wasn't meant to be-I failed the physical test by 2 seconds. So, I decided to go back to school, and I transferred to George Mason University for a year. Even though it was only a year, it allowed me to learn a lot about myself and who I was as a person. I had removed myself from the negative people in my life and learned I wanted more for myself. I still didn't know what I wanted to do, but I knew I wanted to do something that was fulfilling and helpful to people.

I ended up changing my major in my undergraduate degree seven times before finally choosing psychology. In all honesty, I think I chose that at the time because it was the quickest way to graduation. I had no idea what I was going to do with a psychology degree, but I was intrigued by it. I had thought about going into human resources and even went on a couple of interviews before listening to my mother's suggestion to apply to the WVU hospitals and their mental health hospital.

My first job after graduating was as a mental health specialist. I enjoyed the work that I was doing, but I knew that I couldn't make a career out of it. So, with the support and encouragement of my girlfriend (now wife), I applied to graduate school to get my master's degree in counseling. I was hesitant at first because the road to my undergraduate degree was long, but I knew this was what I wanted to do. I have a love and passion for working with people and helping make a difference in their lives, which led me to my counseling degree. I went the school counseling path because I felt like I could make a difference early on in a child's life. From there, the rest is history. 


\section{As a school counselor, you created a comprehensive school counseling program from the ground up. What were the challenges, barriers, and supports during that time?}

Some of the challenges that I faced - and I think a lot of school counselors face when starting or creating something - was changing the perception of school counselors. We always hear the term guidance counselor instead of school counselor, and while they are the same in some ways, they are also very different. As the profession and practice of school counseling have evolved, the roles and responsibilities of counselors in schools have expanded, and this is reflected in the title of professional school counselor. Currently, the profession is trying to move away from the title of guidance counselor. It is outdated and does not represent what school counselors do. When people think of a guidance counselor, they may think of or remember someone that helps you schedule classes and apply to colleges, but the role of the school counselor has expanded far beyond that. School counselors look at ways that we can help students grow. Data is a big component of the work that we do. School counselors can look at academics, attendance, needs assessment data, and student screener data and determine what interventions the school can put in place to help students succeed. These interventions can include group counseling, individual counseling, or participating in a school program (e.g., mentoring program). As you can see, school counselors do more than people think when they hear the title guidance counselor. Everyone must be mindful of this when starting to implement a comprehensive school counseling program. You will likely discover a need to help the community and school personnel understand that not only the title but also the services a professional school counselor can offer have expanded, and the title of guidance counselor is no longer appropriate.

I had to do a lot of explaining and advocating for my role in the school. I had to explain what my true role was and what I could do for administrators, teachers, and families and their students. I had to demonstrate that I could do more than facilitate groups and guidance lessons. To have a comprehensive school counseling program, you need data to drive the work you are doing. I had to show how data could make a difference in the interventions with students. School counselors cannot effectively do their job without the support of the school administration and staff. Data allows us to demonstrate that our interventions are effective in supporting student achievement and development.

Another challenge was trying to stay the course. Creating a program does not happen overnight, and it requires a lot of time and attention. I had to keep reminding myself of the end goal and that there would be days that were harder to deal with, but my end goal was still the same: to have a comprehensive school counseling program. But there were days where I was doing a lot of administrative work that made it tougher. I knew if I kept at it that I would get there. It took 4 years for me to fully create a comprehensive school counseling program.

The process was made easier by the support from the administrators and staff that I worked with. They saw the need for the program and knew how impactful it could be in the students' lives. I can honestly say that without the staff I would not have gotten anywhere close to where I wanted to be.

\section{In your view, what can be done, or needs to change, to address or overcome these challenges and barriers?}

As school counselors, we need to continue to advocate for our profession and the work that we do. If we sit back and don't speak up, then nothing is going to change - the same things will be done year in and year out. We can't be afraid of the reaction and responses that we may get. The answer is always going to be "no" to the question we never ask. 
I also think that as school counselors it is our job to help shape and mold future school counselors. I encourage all school counselors, once you are settled in and ready, to work with local colleges and universities that have school counseling programs and become a supervisor for their students.

I had the pleasure of being a supervisor for students in the school counseling program at WVU for 4 years. It was an honor and privilege to work with those students. It was a way of teaching our future school counselors how to advocate for themselves, their programs, and their profession. I think it is important that we take on these roles. We need to show students how to navigate the challenges and barriers that they will experience as school counselors.

I think the biggest change needs to come from the people that we vote into office. We need to educate political leaders on our role and the job that we do. It is interesting to me that when it comes to education, people making the decisions usually have the least amount of experience. We need laws that protect our jobs and our professional roles. We need laws that require schools to have school counselors, regulate usage of time, establish a counselor ratio to number of students, etc. Having these things in place will allow school counselors to focus their time and energy on building their programs and providing supports for students.

\section{When discussing systemic change and social justice, how do you view your role as a school counselor, and now the Coordinator of Student Supports, when working with school administrators, teachers, parents, and community members?}

This is a very good question, especially now. I view the role of school counselors as vital and important when it comes to discussing systemic change and social justice. In education, you are always following policies. As a school counselor, I have always followed the American School Counselor Association (ASCA) ethical standards. The ASCA ethical standards state that we are ethically responsible to advocate for our students regarding equity and access. It is our role to foster an awareness and understanding of cultural diversity and to ensure that we are creating a welcoming environment for our students.

It is also our role not only to provide support for underrepresented populations in schools, but to educate our students on social justice, cultural diversity, racism, implicit bias, etc. We have an opportunity to help change the world that these students grow up and live in. We cannot be afraid to tackle these sensitive topics. They are a part of our students' world and we need to be prepared to address them.

In my role as Coordinator of Student Supports, I am able to extend my impact with our school administrators, teachers, parents, and community members. I am the county-wide chair over our Diversity, Inclusion, and Equity Committee, a new committee that I was asked to start up when I took my current position. I am very grateful and excited for this opportunity, and I plan to take full advantage of it.

When I started thinking about how I wanted the committee to look, I made sure that it was composed of administrators, teachers, parents, and community members. When we talk about change, we need input from multiple sources throughout the school and community. We need to work as one cohesive unit. I have found it beneficial to involve everyone because we gain more insight. Having parents and community members present really makes a difference because their voice is heard, and we are able to better understand the needs of our students and how to address those needs. I also think it gives stakeholders a little insight into what we are doing as a school system. 


\section{School counselors are often relied upon to be political advocates for students. What has been your experience as an advocate for issues such as social reform, educational policy, administrative functions, and multicultural issues? How can school counselors become more active in advocating for students?}

My experiences regarding these issues have been challenging but also positive. When you discuss any of these issues you will always have two sides. I have always advocated for the best interest of the students; I always want what is best for them. I may be a little different in that I advocate, but I also try and look at the bigger picture. I think so many times when people say they are advocating for one thing or another it can become one-sided. They are only advocating and focusing on the one side. I always take the approach that I need to advocate but also to listen and educate.

I always wanted to understand perspectives from both sides. I felt this always helped me advocate better for students. For example, when it comes to multicultural issues or social reform, I always want to know why some people feel that multicultural issues may not be as big of a deal as they are, or why others feel social reform isn't necessary. If I can stop and listen to both sides, then when I advocate for my students, I have a better understanding of where there seems to be a gap. For me that is how I have been most successful as an advocate. I know I can't go in with an agenda and tell parents or community members how they are wrong about things, because then they will become defensive and all is lost; but if I go in and have a conversation, then in the end it is more productive.

I think that's important for students to see, too. It is important to show students that things are not always going to be how you want them to be. Life is not always going to be kind to you, but keeping a calm head and being able to have constructive conversations will go further than screaming and yelling back and forth.

School counselors can be more active in advocating for students by making sure to speak up when the opportunity presents itself. Advocating does not always need to be on a big stage with politicians involved. I will say that most of the advocating I did for my students was in my office on phone calls or in meetings with parents. Sometimes the small battles are more impactful than the big ones.

\section{Has advocacy changed or shifted with COVID-19? What additional challenges or concerns have emerged due to remote and virtual learning experiences?}

In the situation we are currently living in, with COVID-19 and schools facing decisions of going back to school or staying in a remote setting, I think it is more important than ever to continue to advocate for our students and their needs. A lot of the discussions we hear are about academics and students falling behind academically, which I am not going to argue against. I do not think that our focus should be on academics right now, and my job in advocating for students is to make sure that their social and emotional needs are being met. That is where I will advocate our time and resources need to be spent.

Kids are resilient, but that does not mean that we should act like nothing happened and try and get our students to catch back up academically. We need to check on our students and make sure they are okay and that time is built in throughout their day where they can be a kid and have time to have their social and emotional needs met. That is how I will continue advocating for students during the time we are in, by making sure we do not put social and emotional needs on the back burner - that they are constantly being discussed and things are being put into place to address them. 


\section{What has been your experience when interacting with national and local organizations, such as ACA, ASCA, etc.? Do you feel supported by professional organizations and leaders, and has this changed throughout your career?}

I love our national organizations. I do not think that I could feel any more supported by these professional organizations. I was always skeptical and hesitant to be a part of them due to experiences with non-counseling organizations that left a bad taste in my mouth. With those past organizations, I felt that I was just paying a yearly subscription but not getting anything for it.

I would recommend the American Counseling Association (ACA) or ASCA to anyone that is contemplating membership. My career has been greatly influenced by being a part of national and local organizations. I am very grateful for the opportunities that I have had because of the organizations that I have been a part of. The West Virginia School Counseling Association and ASCA each see the importance in recognizing individuals for the work that they are doing. They are helping make us better professionals through the content that they continue to provide for their members. Being able to put West Virginia School Counselor of the Year and ASCA State Representative on my résumé has been great for me because people take notice of that; they want individuals who are the best at what they do. I know if I ever need something or have a question, all I need to do is reach out to those organizational contacts and they will answer and support me and the work that I am doing.

\section{Throughout your years of practice, what has been your experience when collaborating with other mental health and medical professionals?}

My experiences have been positive when collaborating with other mental health and medical professionals. I think it has been that way because we are seeing each other as vital to the overall success of helping the students that we serve. It is no longer a territorial thing that it might have been in the past. We are finding ways to work together with each other and do what is best for the students.

That is how it needs to be. Not too long ago, before I was a school counselor, I did work as a mobile therapist and I had the capability to go into schools to help support the students that I served. I remember one child who I was working with had a lot of things going on at school, and that was where my focus needed to be. Well, the school did not want me coming into the school or working with the child while in school because they had concerns that there would be problems, as the resident school counselor was also working with this student, and they did not want two different therapeutic approaches being utilized with the student. It is best when you can collaborate with one another and come up with a consistent approach.

I always told myself that one of the first things I would do if I ever became a school counselor would be to build relationships within the community. I recognized the importance of working together and that one person cannot do everything. In my last few years before I took my current position, I set up opportunities for the student support staff in the school (nurses, attendance officer, school social worker, teachers, etc.) to meet and discuss the needs of the students. I would make time to connect with outside agencies to make sure that we were all on the same page and working toward the same goal. This proved to be very beneficial, and I feel that the relationships with our outside mental health and medical professionals are stronger than ever. Being in my new position has also allowed me to continue to build those relationships and coordinate not only at a school level, but at a county level that will benefit all of our schools. 


\section{For future school counselors, what advice would you have regarding their involvement in advancement and future development of the profession?}

My advice for future school counselors is to never settle. We are living in a time where the landscape of school counseling will be changing over the next 5-10 years. I think you will see a greater importance placed on student well-being and student supports. We are understanding more about adverse childhood experiences (ACEs), trauma, brain development, and more. The need for school counselors is higher than ever.

It is up to us, and future school counselors, to step up and take on the challenge. When there is a greater importance placed on a need, it will be closely watched and monitored. If we settle in our roles and keep doing the same things, we won't be successful as a profession. School counselors have a great opportunity right now to change the landscape of our profession. We need to allow ourselves to learn and be open to new things. It is so easy to settle into what you are used to, especially when it is working. Working in the profession, you can get into a rhythm, which isn't always a good thing; sometimes we can get so used to doing the same thing that works that we keep doing it, but we aren't challenging ourselves to see if there is something else out there that works better. My go-to as a primary orientation when working with students is choice theory. I am good at it, and I could probably use that for the rest of my career, but I also know that I can't and shouldn't. Just because it works doesn't mean it is the best for everyone. There may be something better, and we need to allow ourselves to be open to that.

One of the things I've been really proud of is a mentoring program that I started. It mirrored Big Brothers Big Sisters, but I used high school students to come to the elementary school. I trained the students and matched students up based on their shared interests. It was very successful and worked for 3 years. Going into my fourth year, I could have kept things the same, but I knew my results could be better. I changed the age group and some of the activities and had better results. I didn't keep doing something just because it worked; I looked at how to make it better.

Another thing I used to always tell my interns is to not be afraid to take risks. Whenever we are open to trying new things, it opens up a door of possibilities. It makes us even better at what we do. We need to allow ourselves to get to that point. When I was building my program, there were a lot of risks that I had to take. Failure is okay. It means that you tried something. Too many times our fear of failure stops us from trying, but I encourage not only future but current school counselors to take risks and see where it takes you.

This concludes the sixth interview for the annual Lifetime Achievement in Counseling Series. TPC is grateful to Joshua D. Smith, PhD, NCC, LCMHC, LCASA, and Neal D. Gray, PhD, LCMHC-S, for providing this interview. Joshua D. Smith is a counselor at the Center for Emotional Health in Concord, North Carolina. Neal D. Gray is a professor and Chair of the School of Counseling and Human Services at Lenoir-Rhyne University. Correspondence can be emailed to Joshua D. Smith at jsmit643@uncc.edu. 